\title{
PEMBENTUKAN KONSEP DIRI LADY BIKERS PENGGUNA MOTOR CUSTOM DI KOMUNITAS DUCKSTREET GARUT
}

\author{
Haidar Ali ${ }^{1}$, Zikri Fachrul Nurhadi ${ }^{2}$, Heri Hendrawan ${ }^{3}$ \\ Program Studi Ilmu Komunikasi, Universitas Garut ${ }^{1,2,3}$ \\ Email: zikri_fn@uniga.ac.id
}

Naskah diterima tanggal 5 Oktober 2018, direvisi tanggal 10 November 2018, disetujui tanggal 30 Januari 2019

\begin{abstract}
Abstrak. Penelitian ini dilatarbelakangi oleh maraknya pengguna motor custom, yang mana motor custom sangat digemari oleh sebagian kalangan anak muda dan menjadi salah satu subbudaya dikehidupan sehari-harinya. Dalam penelitian ini yang menjadi fokus masalah utama yaitu lady bikers-nya, yang mana hal tersebut merupakan suatu keunikan di mata masyarakat dimana para perempuan menunggangi kuda besi dengan cc yang tinggi dengan tampilan yang unik. Penelitian ini menggunakan pendekatan kualitatif, dan paradigma konstruktivisme. Teknik pengumpulan data yang digunakan wawancara mendalam, observasi non partisipan, dokumentasi, studi pustaka dan gabungan/triangulasi. Peneliti mengambil enam subjek penelitian untuk dijadikan sebagai sumber data yang dilakukan secara purposive sampling. Hasil penelitian menunjukkan bahwa pembentukan sikap pada lady bikers terbentuk oleh faktor pengaruh aktifitas komunitas seperti touring, kopdar dan perakitan motor yang dilakukan oleh para lady bikers di komunitas duckstreet.
\end{abstract}

\section{Katakunci: Konsep Diri, Lady Bikers, Motor Custom, Komunitas Duckstreet.}

Abstract. This research is motivated by the rise of custom motorbike users, where custom motorbikes are very popular among some young people and become one of the sub-cultures in their daily lives. In this study the main focus of the problem was the lady biker, which was a unique thing in the eyes of the community where the women rode an iron horse with a high cc with a unique appearance. This study uses a qualitative approach, and the constructivism paradigm. Data collection techniques used in-depth interviews, non-participant observation, documentation, literature study and combination / triangulation. The researcher took six research subjects to be used as a data source which was carried out by purposive sampling. The results showed that the formation of attitudes in lady bikers was formed by the influence of community activities such as touring, coffee and motorbike assembly carried out by lady bikers in the duckstreet community.

Keywords: Self Concept, Lady Bikers, Custom Motor, Duckstreet Community. 


\section{PENDAHULUAN}

Duckstreet adalah komunitas motor custom yang anggotanya didominasi oleh laki-laki, di dalamnya terdapat anak-anak muda yang menyukai otomotif yang setiap harinya berkumpul dan merakit motor CB menjadi motor custom yang begitu menarik. Akan tetapi selain kaum laki-laki yang menjadi dominasi Komunitas Duckstreet, kini kaum perempuan juga banyak yang menyukai dunia otomotif dan bergabung ke dalam Komunitas Duckstreet. Para perempuan tersebut memiliki hobi yang sama seperti laki-laki, yang mana mereka menyukai motor custom dan menjadikannya sebagai suatu gaya hidup. Munculnya fenomena lady bikers pada Komunitas Duckstreet disebabkan oleh maraknya pengguna motor custom pada saat ini, sangat digemari oleh sebagian kalangan anak muda dan menjadi salah satu sub-budaya dalam kehidupan sosialnya. Hal ini, diperkuat oleh data yang diperoleh dari wawancara dilapangan dengan salah satu informan yang terlihat pada tabel 1 .

Tabel 1

Anggota Komunitas Duckstreet

\begin{tabular}{|c|c|c|c|c|}
\hline No & Nama & Jabatan & Domisili & Tahun \\
\hline 1 & Sony & Ketua & Garut & \multirow{8}{*}{2010} \\
\hline 2 & Asep & Pengurus & Garut & \\
\hline 3 & Fitri & Pengurus & Garut & \\
\hline 4 & Elice & Pengurus & Garut & \\
\hline 5 & Hendra & Anggota & Garut & \\
\hline 6 & Rizal & Anggota & Garut & \\
\hline 7 & Fahmi & Anggota & Garut & \\
\hline 8 & Haikal & Anggota & Garut & \\
\hline 9 & Rizki & Anggota & Garut & \multirow{3}{*}{2011} \\
\hline 10 & Safira & Anggota & Garut & \\
\hline 11 & Hilman & Anggota & Garut & \\
\hline 12 & Sidik & Anggota & Garut & \multirow{5}{*}{$2012-2014$} \\
\hline 13 & Lubis & Anggota & Garut & \\
\hline 14 & Ahmad & Anggota & Garut & \\
\hline 15 & Nono & Anggota & Garut & \\
\hline 16 & Akmal & Anggota & Garut & \\
\hline 17 & Vina & Anggota & Garut & \multirow[b]{4}{*}{2015} \\
\hline 18 & Firman & Anggota & Garut & \\
\hline 19 & Faisal & Anggota & Garut & \\
\hline 20 & Wisnu & Anggota & Garut & \\
\hline 21 & Indra & Anggota & Garut & \multirow{6}{*}{2016} \\
\hline 22 & Cepi & Anggota & Garut & \\
\hline 23 & Elsa & Anggota & Garut & \\
\hline 24 & Deil & Anggota & Garut & \\
\hline 25 & Bela & Anggota & Garut & \\
\hline 26 & Okta & Anggota & Garut & \\
\hline 27 & Reza & Anggota & Garut & \\
\hline
\end{tabular}




\begin{tabular}{|l|l|l|l|l|}
\hline 28 & Chudel & Anggota & Garut & \multirow{2}{*}{2017} \\
\hline 29 & Annisa & Anggota & Garut & \\
\hline 30 & Hani & Anggota & Garut & \\
\hline
\end{tabular}

Sumber : Hasil Wawancara Anggota Komunitas Duckstreet 2017 (Elice, 2017)

Tabel 1 menjelaskan bahwa terjadi peningkatan anggota Komunitas Duckstreet setiap tahunnya, bahwa pada tahun 2010 anggota Komunitas Duckstreet hanya terdiri dari 8 orang dan terjadi peningkatan sampai pada tahun 2017 dengan jumlah anggota mencapai 30 orang dengan klasifikasi anggota komunitas perempuannya yaitu 13 orang. Para perempuan yang tergabung di dalam Komunitas Duckstreet, mereka membentuk sepeda motornya sedemikian rupa dengan berbagai aksesoris otomotif dengan tujuan untuk menciptakan kepuasan tersendiri dalam berkendara. Bahkan mereka menjadikan motor custom-nya sebagai kendaraan sehari-hari dalam menunjang aktivitas hidupnya. Secara tidak langsung didalam Komunitas Duckstreet, ada suatu pengaruh yang menular terhadap perempuan anggota Komunitas Duckstreet. Pengaruh tersebut berupa prilaku, sifat dan pola hidup laki-laki yang kemudian dilakukan oleh para perempuan anggota Komunitas Duckstreet.

Secara khusus di Kota Garut, kini semakin banyak komunitas motor custom dimana anggotanya didominasi oleh kaum laki-laki. Hal tersebut menunjukkan bahwa pengguna motor custom kini semakin banyak dan tersebar di setiap daerah. Seperti halnya kaum laki-laki yang menjadi dominasi pengguna motor custom di suatu komunitas, kini banyak kaum perempuan juga yang sama menggilai dunia otomotif. Perempuan tersebut tergabung dalam komunitas motor custom, dengan mempunyai hobi yang sama yaitu merakit dan menjadi pengguna motor custom di Kabupaten Garut. Hal itulah yang mendorong peneliti untuk melakukan penelitian secara mendalam tentang lady bikers dengan alasan untuk mengetahui bagaimana pembentukan konsep diri lady bikers pengguna motor costum di Komunitas Duckstreet.

Berdasarkan pemaparan yang telah dijelaskan, maka kajian penelitian tentang Pembentukan Konsep diri Lady Bikers relevan dengan penelitian sejenis yang telah dilakukan oleh Bayu saepuloh dengan judul penelitian "Makna Eksistensi Bagi Bikers" dengan tujuan untuk menemukan motif "karena", motif "untuk", motif "agar" dan pengalaman komunikasi bikers, guna memperkuat penelitian yang peneliti lakukan. Hasil penelitian ini menunjukkan bahwa motif "karena" bikers membangun solidaritas karena tidak ingin adanya perpecahan didalam komunitasnnya. Kemudian motif "untuk" bikers melakukan kopdar (kopi darat) bertujuan untuk mendapatkan pengakuan dan keuntungan satu sama lain, peneliti juga menemukan motif yang berorientasi pada masa kini atau motif "agar" dimana, bikers melakukan eksistensi agar menjaga kekompakan dan nama baik kelompoknya. Seorang bikers yang 
tergabung pada komunitas, mempuyai pengalaman komunikasi, baik itu seputar pekerjaan, hobi, maupun dalam komunitas.

Berdasarkan paparan yang telah dijelaskan, maka fenomena Lady bikers ini dapat dikaji oleh Teori Interaksi Simbolik dengan fokus penggunaan suatu konsep tentang Konsep Diri menurut Brooks (dalam Syam, 2012, hal. 61) Konsep Diri merupakan semua perasaan dan pemikiran seseorang mengenal dirinya sendiri. Konsep diri meliputi kemampuan, karakter diri, sikap, tujuan hidup, kebutuhan dan penampilan diri. Those physical, social and phychology perceptions of ourselves that we have derived from experiences and our interactions with others. Konsep diri juga diartikan sebagai pengetahuan dan keyakinan yang dimiliki individu tentang karakteristik dan ciri-ciri pribadinya. (Worchel 2000 dalam Syam, 2012, hal. 61)

Adapun alasan peneliti mengambil objek penelitian pada Komunitas Duckstreet ini, karena Komunitas Duckstreet merupakan salah satu komunitas motor custom lokal di Kabupaten Garut yang sudah berdiri lama sejak tahun 2010 hingga sekarang, dan merupakan salah satu pelopor bagi komunitas-komunitas motor custom lainnya untuk mendirikan sebuah komunitas motor custom di Kabupaten Garut. Dengan begitu Komunitas Duckstreet akan membawa dan memberikan informan yang kompeten dengan memiliki pengalaman yang panjang sebagai seorang Lady Bikers untuk dijadikan sumber data/informan penelitian oleh peneliti. Serta alasan pemilihan subjek pada lady bikers, selain untuk mengembangkan dan menambah keragaman subjek penelitian yang dilakukan oleh mahasiswa/i Fakultas Ilmu Komunikasi Universitas Garut, peneliti juga mempunyai alasan karena lady bikers masih dipandang sebagai suatu kegiatan yang langka dan unik di Kabupaten Garut. Lady Bikers mempunyai penampilan, karakter diri serta sikap yang berbeda dengan perempuan pada umumnya, hal tersebutlah yang menjadi unsur pandangan masyarakat tentang kelangkaan dan keunikan kegiatan lady bikers dikalangan masyarakat Kabupaten Garut. Hal itulah yang mendorong peneliti untuk melakukan penelitian secara mendalam terhadap lady bikers dengan alasan untuk mengetahui pembentukan konsep diri lady bikers pengguna motor costum di Komunitas Duckstreet.

Atas dasar pemaparan yang telah dijelaskan, maka peneliti tertarik untuk melaksanakan penelitian mengenai pembentukan konsep diri di kalangan perempuan yang tergabung kedalam sebuah komunitas motor costum, khususnya pada perempuan yang tergabung pada Komunitas Duckstreet, dengan tujuan untuk menjelaskan tentang bagaimana model komunikasi tentang pembentukan konsep diri pada lady bikers pengguna motor costum yang meliputi karakter diri, sikap, kebutuhan, penampilan diri dan tujuan hidup lady bikers pengguna motor costum di Komunitas Duckstreet Kabupaten Garut. 


\section{METODE PENELITIAN}

Paradigma penelitian terkait dengan judul pembentukan konsep diri Lady Bikers adalah paradigma konstruktivis yaitu paradigma yang memandang ilmu sosial sebagai analisis sistematis terhadap socially meaningful action melalui pengamatan langsung dan rinci terhadap pelaku sosial dalam setting keseharian yang alamiah, agar mampu memahami dan menafsirkan bagaimana para pelaku sosial yang bersangkutan menciptakan dan memelihara/mengelola dunia sosial mereka (Nurhadi \& Din, 2012: 27). Penelitian ini menggunakan Metode kualitatif agar dapat menjelaskan tentang Pembentukan Konsep Diri Lady Bikers di Komunitas Duckstreet. Teknik pengumpulan data pada penelitian ini melalui wawancara mendalam, observasi non partisipan, dokumentasi, studi pustaka dan gabungan/triangulasi. Peneliti mengambil enam subjek penelitian untuk dijadikan sebagai sumber data yang dilakukan secara purposive sampling.

\section{HASIL PENELITIAN DAN PEMBAHASAN}

Berdasarkan hasil penelitian melalui wawancara dengan para informan, pembentukan sikap menggambarkan bahwa konsep diri mengenai pembentukan sikap pada lady bikers terbentuk oleh 4 macam elemen yaitu adopsi, diferensiasi, integrasi dan trauma (Smartpiskologi: 2018). Seperti halnya pada informan pertama yaitu Fitri yang mana dirinya memiliki sikap sedikit seperti laki-laki, disini penulis menyimpulkan bahwa hal tersebut di adopsi Fitri dari lingkungan sekitarnya dengan di dorong oleh aktifitas sebagai seorang montir yang mana hal tersebut akan memberikan dampak dalam pembentukan sikapnya. Selain itu, faktor integrasi juga merupakan faktor penyebab selanjutnya, yang mana ada peristiwa yang menjadi akumulasi teradopsinya aktifitas-aktifitas di dalam komunitas yang kemudian menjadi dasar sebagai suatu pengalaman yang kemudian membentuk sikap pribadinya.

Adapun untuk elemen diferensasi dalam pembentukan sikap seseorang di tunjang oleh faktor intelegensi yang berkembang, faktor usia, pengalaman dan faktor sejenis yang berkembang menjadi pandangan tersendiri. Hal tersebut serupa dengan pandangan Elice dan Fira yang mana kedua informan ini memiliki faktor pengaruh yang sama yaitu dari keluarga, yang kemudian faktor tersebut berkembang seiring dengan perkembangan intelegensi,umur serta pengalaman dari diri kedua informan tersebut. Kemudian terjadi perkembangan dari apa yang disukainya dengan ditunjang oleh faktor pengalaman yang dialaminya, maka terbentuklah sikap dirinya karena ada faktor utama yang menjadi dasar yang kemudian di berkembang seiring pertumbuhan intelegensi serta pengalaman diri pribadinya. 
Dalam pembentukan sikap ada faktor trauma juga, yang mana faktor tersebut memberikan kesan dalam suatu peristiwa atau aktifitas yang dialami oleh seseorang. Seperti 3 informan yaitu Vina, Elsa dan Lenny merasa terkesan oleh peritiwa atau aktifitas yang ada di lingkungan mereka. Faktor trauma memberikan kesan mendalam terhadap para informan tersebut, mereka tidak terhenti dengan hanya mengendarai motor-motor custom tetapi mereka jauh lebih mendalam dengan mengikuti aktifitas seputar dunia permotoran seperti bergabung ke dalam komunitas motor dan kemudian mengikuti aktifitas yang ada didalamnya.

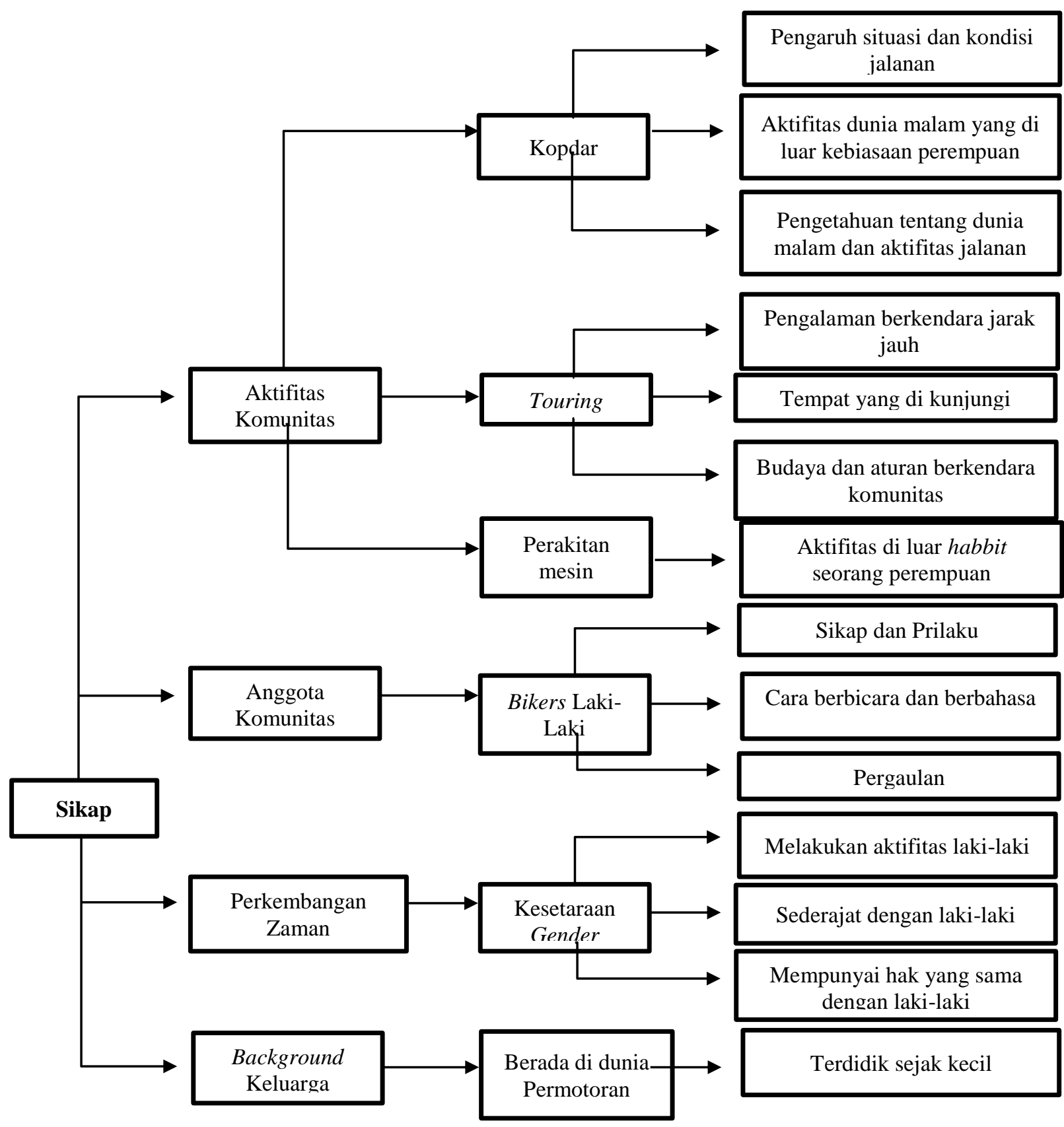

Gambar 1

Model Pembentukan Sikap Lady Bikers Di Komunitas Duckstreet

Sumber: Model Kategorisasi wawancara (diadopsi dari informan, 2018) 
Secara garis besar, menurut hasil wawancara yang dilakukan bahwa informan memiliki karakter diri yang beragam yang disebabkan oleh lingkungan yang di mana mereka ada dalam ranah aktifitasnnya. Menurut Sutardjo bahwa karakter diri seseorang dapat berubah dan disebabkan pua oleh bawaan atau pengaruh internal, seperti halnya pada beberapa informan yaitu Fitri, Elice dan Fira yang mana mereka terpengaruh atau terdorong oleh faktor internal yang mana keluarganya merupakan keluarga yang menyukai dunia permotoran. Hal itu merupakan faktor dasar dalam pembentukan krakter diri meraka, selain itu faktor lingkungan dari komunitas pun merupakan salah satu faktor penyebab dalam pembentukan karakter diri para lady bikers ini, seperti halnya aktifitas-aktifitas yang dilakukan dalam komunitas seperti kopdar, touring, perakitan motor dan aktifitas lainnya.

Selain faktor-faktor yang telah disebutkan, dalam pembentukan karakter diri para lady bikers ini disebabkan oleh pengaruh anggota komunitas lainnya yaitu anggota laki-laki. Anggota laki-laki sangat memberikan dampak yang signifkan dalam pembentukan karakter diri, yang mana pola prilaku mereka sebagian akan ditiru oleh anggota perempuan dan akan melekat pada diri anggota perempuan yang kemudian menjadi watak dan karakter diri para lady biker ini. Situasi kondisipun memberikan peran dalam pembentukan karakter diri lady bikers di Komunitas Duckstreet, seperti hla nya situasi kondisi jalanan pada saat melakukan aktifitas kopdar maupun touring, yang mana akan ada pengalaman yang di adopsi sebagai suatu peristiwa yang kemudian akan diterapkan jikalu peristiwa tersebut terjadi lagi.

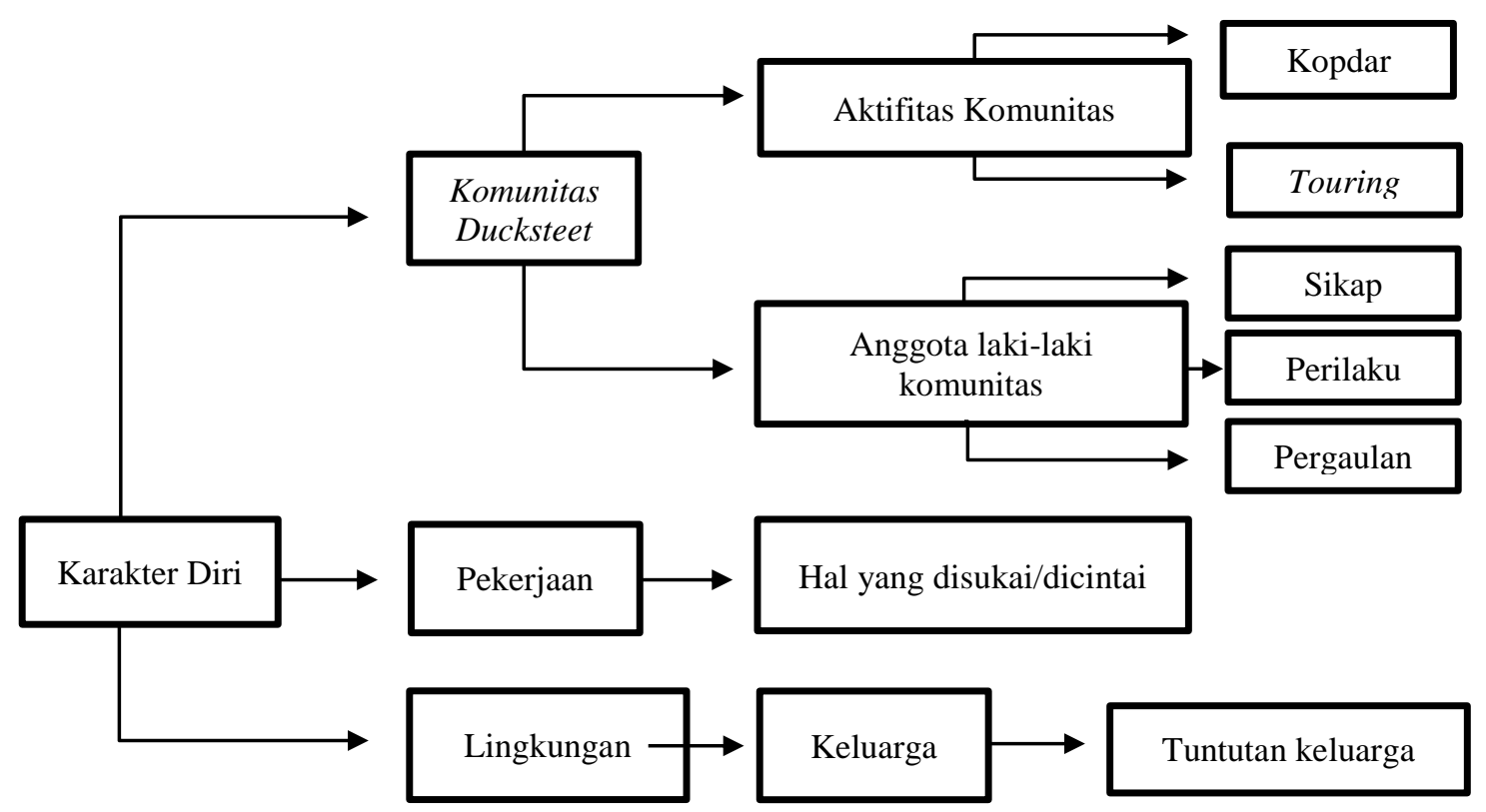

Gambar 2

Model Pembentukan Karakter Diri Lady Bikers Di Komunitas Duckstreet

Sumber: Model Kategorisasi wawancara (diadopsi dari informan, 2018) 
Pada umumnya semua informan yaitu para lady bikers yang tergabung di Komunitas Duckstreet memiliki kebutuhan yang sama, yaitu kebutuhan-kebutuhan untuk melengkapi fasilitas atau kebutuhan alat dalam sarana aktifitas seputar dunia permotorannya yang terdiri dari beberapa kebutuhan yaitu Physical Needs (Kebutuhan-kebutuhan fisik), Safety Needs (Kebutuhan-kebutuhan rasa aman), Social Needs (Kebutuhan-kebutuhan sosial), Esteem Needs (Kebutuhan-kebutuhan penghargaan), Self Actualization (kebutuhan aktualisasi diri). Kebutuhan ini merupakan kebutuhan tertinggi dari individu dan kebutuhan ini sekaligus paling sulit dilaksanakan. (Santoso, 2010 hal 111-112).

Seperti halnya informan pertama yaitu Fitri, yang mana dirinya mengungkapkan bahwa ia membutuhkan pendanaan untuk membesarkan bengkel motornya, dengan tujuan untuk menambah konsumen dan penghasilan untuk dirinya, selain itu ia mengungkapkan bahwa dengan adanya pendanaan yang besar maka ia bisa merakit motor baru sesuai keinginannya. Akan tetapi berbeda dengan informan lainnya yang mana mereka mengungkapkan bawa kebutuhan-kebutuhannya masih dalam ranah penampilan, seperti halnya jaket, sepatu dan lain sebagainya. Hal itu ditujukan untuk menunjukkan aktualisasi dirinya sebagai anak motor, dan kebutuhan lainnya masih seputar kebutuhan-kebutuhan untuk pemenuhan perlengkapan touring.

Merujuk pada pemaparan diatas yang dikemukakan oleh Abraham Maslow, bahwasannya kebutuhan-kebutuhan yang dibutuhakan oleh para lady bikers ini masuk dalam pemaparan tersebut. Yang mana dalam kebutuhan untuk pemenuhan keinginannya baik itu kebutuhan alat, fasilitas dan lain sebagainya masuk dalam kebutuhan Phsycal needs. Dalam kebutuhan Phsycal needs ini Abraham Maslow mengungkapkan bahwa manusia mempunyai keinginan untuk memenuhi kebutuhannya yang berkenaan dengan kebutuhan pangan, sandang, dan papan. Serta kebutuhan lainnya seperti halnya kebutuhan untuk menunjukan aktualisasi dirinya sebagai seorang Lady Bikers tersebut, masuk dalam kebutuhan Self Actualization.

Berbeda dengan informan terakhir yaitu Lenny, ia mengungkapkan bahwa selain kebutuhan-kebutuhan lainnya yang sama dengan kebuthhan lady bikers pada umumnya, ia mengungkapkan bahwa dirinya membutuhkan sraan aktifitas lain, yaitu sarana untuk memerkan hasil dari karya rakitan motornya tersebut. Dengan begitu para lady bikers maupun bikers lainnya dapat mempunyai suatau ruang atau wadah untuk menampilkan hasil karya rakitanrakitan motornya sendiri. Selain itu Lenny juga mengungkapkan bahwa dirinya mempunyai plan untuk kedepannya ingin membawa arah para anggota komunitas motor khusunya Komunitas Duckstreet kearah yang lebih positif, dengan begitu maka para anggota komunitas motor dapat mempunya suatu citra yang positif di kalangan masyarakat umum. Meninjau kembali pada pemaparan Abraham Maslow tentang kebutuhan, bahwa kebutuhan-kebutuhan yang informan 
Lenny ungkapkan ini masuk kedalam ranah kebutuhan Safety Needs, Social Needs, Esteem Needs.

Penulis menyimpulkan bahwa pemaparan dari Lenny tersebut masuk kedalam ranah kebutuhan tersebut karena pada dasarnya para lady bikers membutuhan kebutuhan sosial seperti diakui oleh masyarakat, kebutuhan keamanan dalam menjalankan aktifitasnya sebagai anggota sebuah komunitas motor, serta kebutuhan penghargaan atas sebuah karya yang mereka telah ciptakan, yaitu dengan mengikuti sebuah kontes atau pameran rakitan motor, yang mana hal tersebut dapat memberikan kepuasan terhadap para lady bikers tentang apa yang mereka telah ciptakan dari sebuah rakitan kuda besinya. Dengan begitu mereka akan merasa terpenuhi dalam segi kebutuhan mereka dalam aktiftas seputar dunia permotorannya serta mempunyai output yang jelas dalam setiap aktifitas yang mereka lakukan.

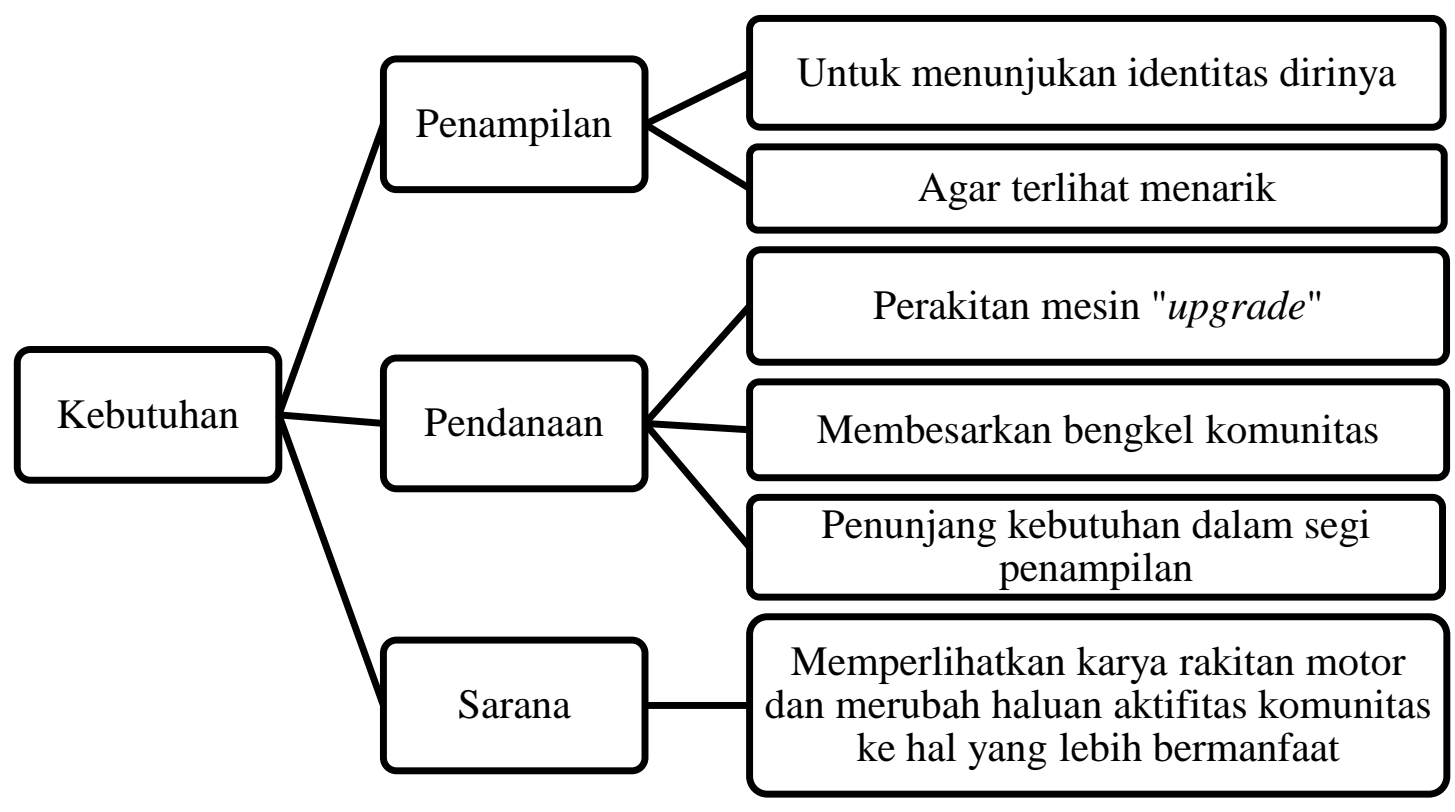

Gambar 3

\section{Model Kebutuhan Lady Bikers Di Komunitas Duckstreet}

Sumber: Model Kategorisasi wawancara (diadopsi dari informan, 2018)

Penulis menggambarkan bahwa tentang penampilan diri seorang lady bikers di Komunitas Duckstreet mereka sama halnya bertujuan untuk menunjukan diri mereka siapa. Akan tetapi disini tentang penampilan diri mereka yaitu lady bikers, kebanyakan tidak memperdulikan tentang apa yang menjadi pandangan orang lain terhadap dirinya sebagai seorang lady bikers, seperti halnya pada informan pertama yaitu fitri yang mana dirinya mempunyai anggapan bahwa tentang penampilan dirinya itu merupakan suatu hak yang dimiliki oleh dirinya, sehingga orang lainpun tidak punya hak untuk melarang dirinya berpenampilan seperti dirinya pada saat sekarang ini, pikirnya yang penting dirinya nyaman dengan penampilan yang ia kenakan pada 
keehariannya. Selain itu disisi lain fitri tidak memperdulikan apa yang menjadi tanggapan tentang dirinya, ia hanya beranggapan jadilah diri sendiri tanpa memperdulikan apa yang dikatakan oleh orang lain dan jalani sepanjang nyaman. Adapun mengenai tanggapan orang lain tentang penampilan dirinya, ia beranggapan bahwa hal tersebut merupakan suatu resiko, karena segala sesuatu ada resikonya, pungkas fitri seperti itu. Disini penulis menyimpulkan bahwa hal tersebut adalah bagian dari pertunjukan identitas dan kepribadian diri dari seorang Fitri selaku lady biker yang sesuai dengan pemaparan yang telah di paparkan diatas di paragraf sebelumnya.

Sama halnya dengan Fitri, disini informan kedua yaitu Elice dan Informan ketiga yaitu Fira, mereka mengungkapkan bahwa dengan penampilan dirinya sekarang mereka merasa enjoy saja dengan anggapan tidak memperdulikan pandangan orang lain terhadap dirinya. Mereka beranggapan bahwa inilah hidup saya maka terserah saya maka dari itu mereka tidak memperdulikan apa yang menjadi pandangan orang lain terhadap dirinya tersebut. Disisi lai terlepas dari apa yang mereka paparkan mengenai tidak perdulinya mereka terhadap pandangan orang lain, bahwa dengan mereka mempunyai penampilan seperti itu yaitu layaknya seorang lady bikers hal tersebut merupakan salah satu jalan untuk mengekspresikan dirinya sebagai seorang lady bikers, adapun penampilan tersebut terjadi karena disebakan oleh fakor-faktor role model yang mereka ikut.

Kemudian untuk informan yang ke Lima yaitu Elsa, ia merupakan slaah stau lady bikers yang mempunyai penampilan tomboy dengan mengenakan pakaian serba hitam, masih sama dengan para informan yang sebelumnya walaupun terdapat suatu perbedaan, disisi lain hal tersebut masih ada dalam bidang yang sama yaitu untuk menunjukan siapa dirinya dan merupakan salah satu jalan untuk mengekspresikan diri tentang sesuatu hal yang diikutinya. Akan tetapi untuk informan selanjutnya yaitu Vina dan Lennya, mereka tidak terlalu ada dalam suatu bidang untuk menunjukan siapa dirinya dan mengekspresikan apa yang menjadi aktifitasnya, mereka masih konsisten dengan gaya penampilan berjilbab seperti wanita pada umumnya, karena mereka beranggapan berjilbab bukan alasan untuk tetap bisa menjadi seorang lady bikers. Disini penulis merujuk pada pemaparan yang sudah di jelaskan di awal yang mana hal tersebut merupakan suatu kontrol yang dilakukan oleh kedua informan tersebut dalam memainkan dan mengontrol peranan mereka sendiri. Sehingga mereka tetap berada dalam koridor sebagai seorang perempuan yang wajib behijab dan menunjukan identitas dirinya sebagai seorang lady bikers yang masih taat dan patuh pada suatu norma agama yang wajib dijalankannya. Kesemuanya itu adalah demi penampilan karena penampilan adalah segalagalanya, dan segala-galanya adalah penampilan. Dengan penampilan seseorang bisa menunjukkan siapa dirinya (Hendariningrum: 2018). 


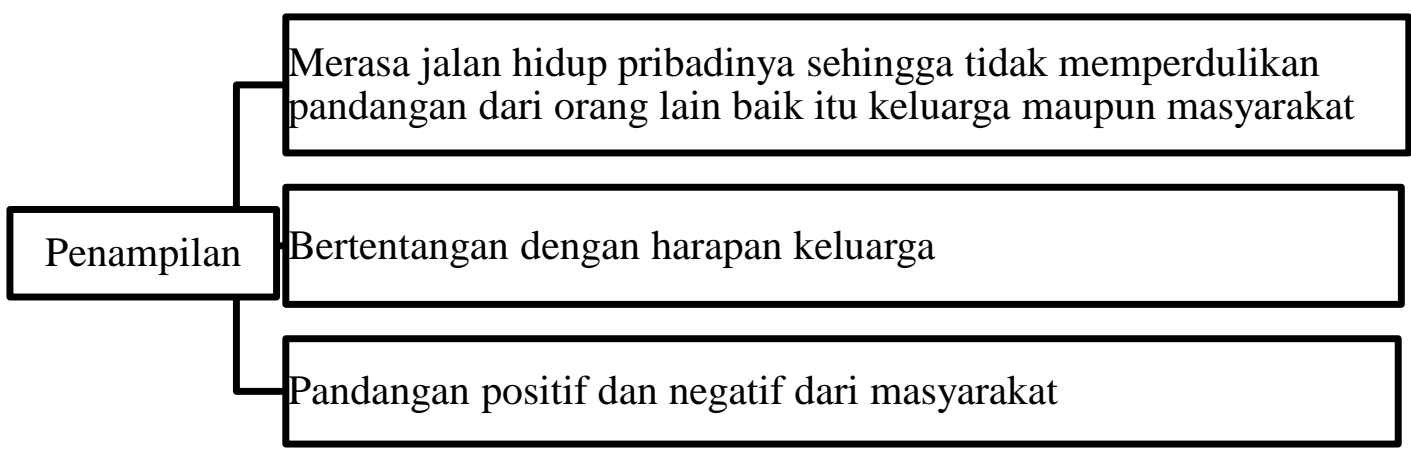

\section{Gambar 4}

Model Penampilan Diri Lady Bikers Di Komunitas Duckstreet

Sumber: Model Kategorisasi wawancara (diadopsi dari informan, 2018)

John Dewey menyebutkan bahwa perbedaan yang jelas antara mahluk hidup dan benda mati adalah bahwa mahluk hidup memelihara kelanjutan hidupnya dengan terciptanya pembaharuan dalam dirinya dan mahluk tidak hidup atau benda mati tentu sebaliknya. Diantara mahluk hidup itu terdapat manusia, manusia itu selama hidupnya berusaha dan berjuang untuk memanfaatkan alam sekitarnya, terutama sekali dia mempergunakan daya dan tenaga alam untuk kepentingan dirinya.

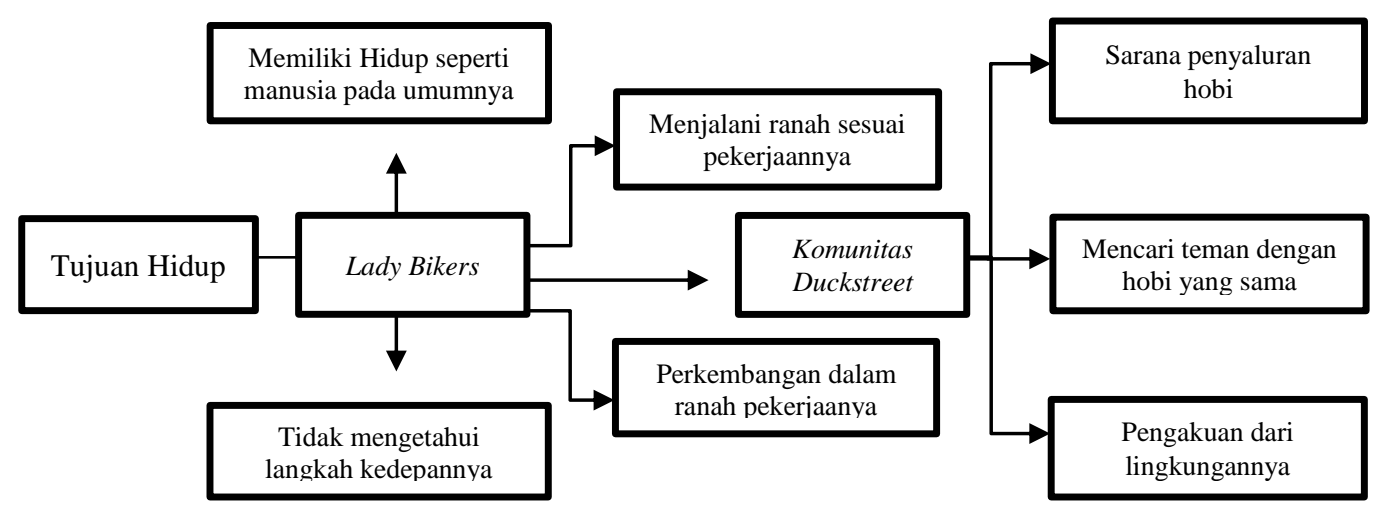

\section{Gambar 5}

\section{Model Tujuan Hidup Lady Bikers Di Komunitas Duckstreet}

Sumber: Model Kategorisasi wawancara (diadopsi dari informan, 2018).

Tujuan hidup bagi makhluk hidup merupakan suatau pembaruan diri sendiri melalui tindakannya mengendalikan lingkungannya, penulis beranggapan bahwa sama halnya dengan tujuan hidup para lady bikers di Komunitas Duxkstreet. Terlepas dari apa yang mereka paparkan mengenai tujuan hidupnya, intinya para lady bikers sebagai makhluk hidup bertujuan untuk terus menerus memperbaharui hidupnya dengan mengejar apa yang di inginkannya karena hidup bagi mahluk hidup adalah proses pembaharuan diri sendiri melalui tindakannya mengendalikan lingkungannya. Seperti yang dipaparkan oleh informan pertama yaitu fitri, yang mana dirinya memaparkan bahwa untuk kedepannya ia mengingkan hal-hal yang lebih baik dari pada saat ini, 
maksudnya seperti yang dipaparkan dalam pertanyaan sebelumnya yang merujuk pada pedoman wawancara, fitri memaparkan bahwa untuk kedepannya ia menginginkan perluasan bengkel, rakitan motor baru dan lain sebagainya. Hal tersebut merupakan salah satu tujuan dalam hidupnya yang sama halnya sama dengan pemaparan yang di paparkan oleh John Dewey yaitu manusia sebagai mahluk hidup menginginkan pembaharuan dalam hidupnya.

Adapun untuk informan selanjutnya yaitu Elice, ia memaparkan dalam tujuan hidupnya yaitu menginginkan kehidupan seperti orang pada umumnya. Maksudnya yaitu seperti berkeluarga, bekerja dan mempunyai keturunan, adapaun untuk tujuan dirinya mengikuti aktifitas di Komunitas Duckstreet ia memaparkan hanya sebagai penyaluran hobi dalam bidang yang ia sukai, serta untuk mempunyai suatu histori yang mengesankan dalam hidupnya yang sesuai dengan apa yang dirinya sukai agar mempunyai suatu cerita bagi anak-anaknya kelak. Sama halnya dengan informan selanjutnya yaitu Vina yang mana dirinya mengungkapkan bahwa tujuan dirinya dalam keaktifannya di dunia motor, yaitu hanya sebatas penyaluran hobi dan agar banyak teman, dan untuk informan ke enam yaitu Lenny ia pun mengungkapkan bahw keikut sertaan dirinya ke dalam dunia motor, tujuannya hanya untuk menyalurkan hobi dan hiburan, terlepas dari pengaruh yang pasangannya bawa.

Akan tetapi untuk informan lainnya yaitu Fira, ia mengungkapkan bahwa tujuan dalam hidupnya yaitu dengan bergabungnya ke dalam suau komunitas motor, ia merasa mempunyai suatu keluarga baru. Hal tersebut diungkapkan Fira karena dirinya sudah terlanjur masuk ke dalam dunia permotoran dengan pengalaman kelam di dunia geng motor, maka dari itu dia memutuskan bahwa bergabung dirinya kedalam sebuah komunitas motor yaitu merupakan suatu tujuan hidup. Berbeda pula dengan Elsa, ia mengungkapkan bahwa tujuan utama hidupnya yaitu ingin menjadi apoteker, karena sesuai engan pekerjaannya saat ini, adapun dalam penggabungan dirinya kedalam komunitas motor yaitu Komunitas Duckstreet yaitu sebagai sarana penyaluran hobi dan tempat bermain. Dan untuk keseluruhan informan terkecuali Fira, mereka mengungkapkan bahwa mereka tidak tahu sampai kapan mereka akan bergabung kedalam suatu komunitas motor, akan tetapi sepanjang mereka bisa untuk bergabung, mereka akan tetap bergabung dengan mengikuti segala aktifitasnya.

\section{SIMPULAN}

Pembentukan sikap pada lady bikers di Komunitas Duckstreet dapat disimpulkan dari pengadopsian tingkah prilaku dalam kehidupan sehari-hari mereka terkait aktifitas mereka di dalam komunitas yang mereka ikuti. Pengadopsian tersebut diperoleh mereka pertama dari sesama anggota komunitas, kedua dari aktifitas mereka seperti touring, kopdar dan perakitan 
mesin motor. Faktor diferensasi juga merupakan faktor pengembangan intelegensi manusia secara kodrati, hal tersebut menjadikan mereka memandang suatu aktifitas yang mereka lakukan dengan merujuk pada faktor pola pikir mereka saja. Kemudian faktor terakhir yaitu faktor integrasi dan trauma, yang mana ada pengalaman yang bertahap dari aktifitas yang mereka lakukan setiap harinya.

Pembentukan karaker diri pada lady bikers di Komunitas Duckstreet dapat disimpulkan terbentuk oleh faktor pengualifikasian diri, yang mana faktor tersebut merupakan suatu kebiasaan yang dilakukan setiap hari yang kemudian menjadi suatu kebiasaan pada diri seseorang. Seperti halnya pada lady bikers di Komunitas Duckstreet yang mana keseharian mereka diisi dengan aktifitas seputar dunia permotoran seperti perakitan mesin motor, kopdar dan touring ataupun aktifitas lainnya yang terkait dengan dunia otomotif, hal tersebut menjadi suatu kebbiasaan yang mereka lakukan dalam kesehariannya yang kemudian melekat dan menjadi suatu karakter, sifat atau bisa dikatakan sebagai suatu cap tetap tentang diri pribadinya.

Kebutuhan lady bikers di Komunitas Duckstreet tidak terlepas dalam kebutuhan material, hal tersebut ditujukan mereka untuk memenuhi kebutuhan-kebutuhan mereka dalam aktifitas perakitan motor, pembelian aksesoris motor serta pembelian busana yang akan menunjukan tentang citra diri mereka sebagai seorang anak motor. Selain itu keutuhan para lady bikers di Komunitas Duckstreet tidak terlepas dalam kebutuhan aktualisasi diri mereka sebagai seorang lady bikers, jadi apapun yang mereka lakukan terkait aktifitas permotoran maupun busana yang mereka kenakan hal tersebut di tujukan sebagai suatu kegiatan aktualisasi diri mereka agar orang lain tau bahwa dirinya merupakan seorang anak motor.

Dalam Penampilan diri, kebanyakan para lady bikers memiliki tampilan seperti laki-laki layaknya, yang mana hal tersebut merupakan suatu etalase kecil untuk menunjukan tentang siapa dirinya dan merupakan suatu cara untuk menunjukan aktualisasi dirinya sebagai anak motor. Dengan tujuan agar orang lain tau tentang dirinya siapa, aktifitasnya apa dan kesibukannya seperti apa.

Tujuan hidup merupakan suatau pembaruan diri sendiri melalui tindakannya mengendalikan lingkungannya, terlepas dari apa yang mereka paparkan mengenai tujuan hidupnya, intinya para lady bikers sebagai makhluk hidup bertujuan untuk terus menerus memperbaharui hidupnya dengan mengejar apa yang di inginkannya. Menyesuaikan apa yang diharapkan olehnya sesuai dengan keadaan yang sedang di jalankannya. Adapaun tujuan diluar keterkaitan dengan dunia permotoran, para lady bikers memang sama dengan orang pada umumnya, yaitu mempunyai mimpi dengan berkeluarga dan mempunyai keturunan. 


\section{DAFTAR PUSTAKA}

\section{Buku:}

Adisusilo, S. 2013. Pembelajaran Nilai Karakter. Jakarta: Jakarta: PT. Raja Gravindo Persada. Ardianto, E. 2014. Metodologi Penelitian Untuk Public Relations. Bandung: Simbiosa Rekatama Media

Coopersmith. 2002. Konsep Diri: Self Esteem. Ponorogo: Unmuh Meolong, Lexy. 2007. Metode Penelitian Kualitatif. Bandung : Remaja Rosdakarya Nurhadi. 2015. Teori-Teori Komunikasi. Bogor: Ghalia Indonesia.

Nurhadi, Zikri Fachrul \& Din, A.h Makbul. 2012. Metode Penelitian Kualitatif. Bandung: Alfabeta

Santoso, S. 2010. Teori-Teori Psikologi Sosial. Bandung: Refika Aditama.

Sugyiono. 2005. Metode Penelitian Administrasi. Bandung: Alfabeta

Sugyiono. 2009. Metode Penelitian Kuantitatif, Kualitatif dan $R \&$ D. Bandung: Alfabeta

Syam, Nina Winangsih. 2012. Psikologi Sosial. Bandung: Remaja Rosdakarya. 